\title{
Four new species of deep water agglutinated foraminifera from the Oligocene-Miocene of the Congo Fan (offshore Angola)
}

\author{
Severyn Kender, ${ }^{1}$ Michael A. Kaminski ${ }^{1}$ and Robert W. Jones ${ }^{2}$ \\ ${ }^{1}$ Department of Earth Sciences, University College London, Gower Street, London, WC1E 6BT, U.K. \\ ${ }^{2}$ BP Exploration, Chertsey Road, Sunbury-on-Thames, London, TW16 7LN, U.K. \\ email: s.kender@ucl.ac.uk
}

\begin{abstract}
Four new species of deep-water agglutinated benthic foraminifera are described from the Oligocene and Miocene of the Congo Fan, offshore Angola. Scherochorella congoensis n.sp., Paratrochamminoides gorayskiformis n.sp., Haplophragmoides nauticus n.sp. and Portatrochammina profunda n.sp. all occur in deep-sea turbiditic shales and sands from the distal section of the Congo Fan.
\end{abstract}

\section{INTRODUCTION}

The Congo Fan is a terrigenous wedge largely built of Oligocene and Miocene prograding turbidite deposits organised into thick sedimentary packages containing paleocanyons, meandering paleochannels, and overbank deposits (Anka and Séranne 2004, Babonneau et al. 2002 and Lavier et al. 2001). Although the Congo Fan has been an oil company target for many years, surprisingly few micropalaeontological studies have been published from the area (e.g. Preece et al. 1999, 2000).

The species described in this study derive from the Oligocene section of an exploration hole drilled in the distal part of the Congo Fan (text-fig. 1). The foraminifera are almost entirely agglutinated indicating deposition beneath a locally raised $\mathrm{CCD}$, and are present in most samples at medium to low abundances (that suggest a paleobathymetry of mid to lower bathyal). Typical cosmopolitan Paleogene forms can be identified along with several species that appear to be new and are here described for the first time. Some of these forms are also present in the Miocene section.

The purpose of this paper is to provide formal descriptions of new agglutinated species from the Oligocene of the distal Congo Fan. A more complete description of the micropaleontology of the Congo Fan is the subject of a Ph.D. thesis at UCL (Kender, in prep.).

\section{MATERIAL AND METHODS}

Sample material for this study consists of ditch-cutting samples from an exploration well drilled at water depth of $2,027 \mathrm{~m}$ in Block 31, offshore Angola. The well penetrated clastic sediments at the base of the Congo Fan. Samples from the well were collected at $10 \mathrm{~m}$ spacing, and in this well the Oligocene samples (as determined by calcareous nannofossils) occur over an interval from $3,460 \mathrm{~m}$ to $4,270 \mathrm{~m}$ (below rotary table). The Oligocene section in the well consists of predominantly black mudstones and siltstones with interbedded sandy horizons. Samples were disaggregated by boiling in a sodium carbonate solution, passed over a $63 \mu \mathrm{m}$ sieve, and foraminifera were mounted onto cardboard reference slides. Selected specimens were imaged using a JEOL JSM-648OLV SEM at University College London, and digital plates were made using Adobe Photoshop.

Type specimens of new species described herein are deposited in the Department of Palaeontology, Natural History Museum, London, and in the authors' collection at University College London. The species are described below, using the suprageneric classification of Kaminski (2004).

\section{SYSTEMATIC DESCRIPTIONS}

Subclass TEXTULARIIA Mikhalevich 1980

Order LITUOLIDA Lankester 1885

Suborder HORMOSININA Mikhalevich 1980

Superfamily HORMOSINACEA Haeckel 1894

Family KUNKLERINIDAE Rauser and Reitlinger 1986

Genus Scherochorella Loeblich and Tappan 1984

Scherochorella congoensis Kender, Kaminski and Jones n. sp. Plate 1, figures 1-6

Material: 1213 specimens from 31 samples, Upper Oligocene.

Type locality: Congo Fan, offshore Angola, Block 31.

Type level: Cuttings sample collected at 4,040 meters below rotary table. Oligocene black shales.

Type specimens: Holotype (BMNH PF 67318) and paratypes (BMNH PF 67319) are deposited in the micropalaeontological collections of the Natural History Museum, London.

Derivation of name: After the Congo Fan, the location of its discovery.

Description: Test free ( $800 \mu \mathrm{m}$ in length, $150 \mu \mathrm{m}$ in width), uniserial, consisting a rectilinear series of 9-10 chambers increasing in size slowly from an initial, small proloculus. Successive 


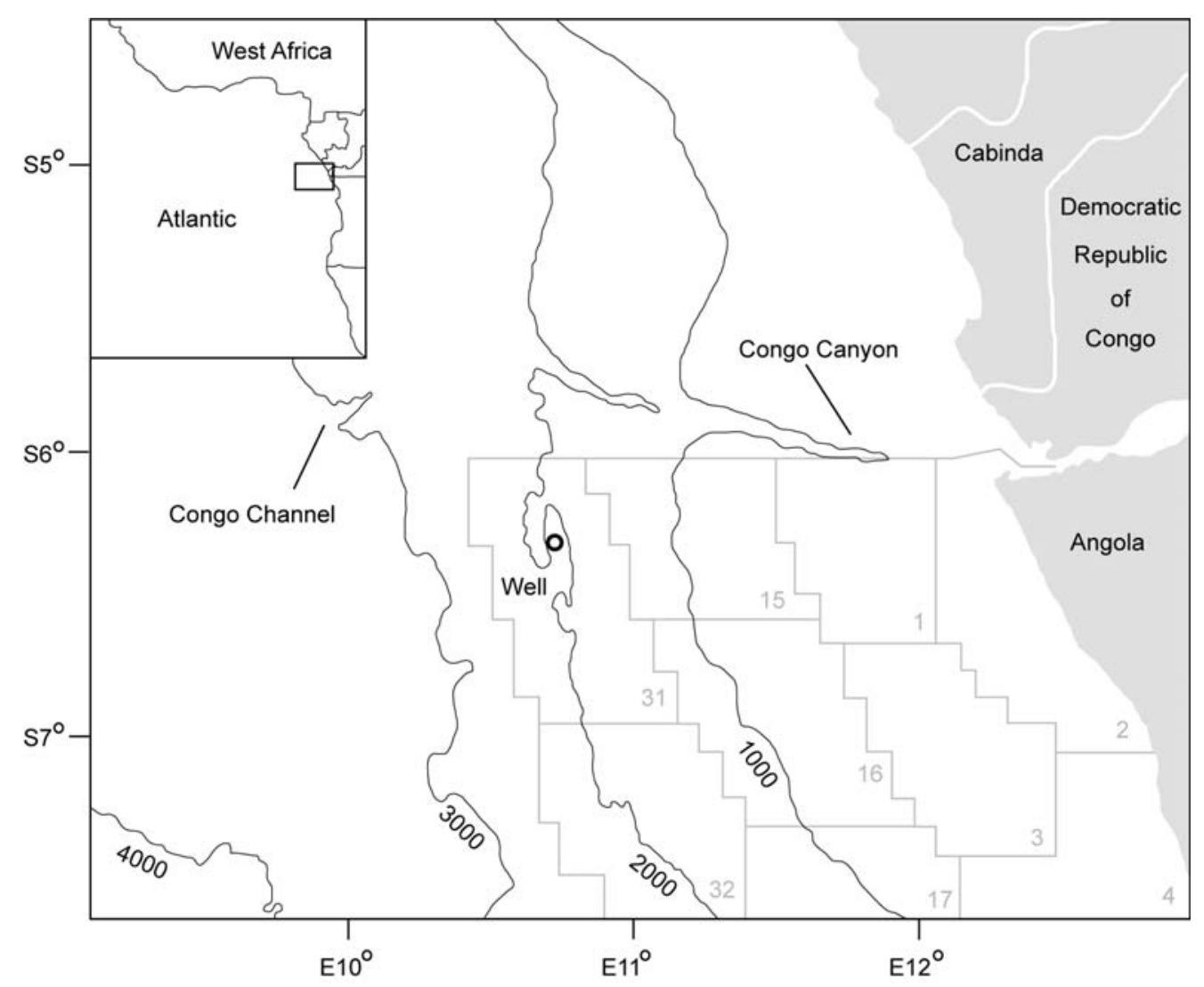

TEXT-FIGURE 1

Location map of study area showing approximate location of studied well within Block 31 .

chambers overlap previous ones by approximately $30 \%$. Sutures depressed and straight. Specimens are invariably flattened in various planes. Wall thin, composed of a single layer of coarsely agglutinated sand grains 2-3 grains thick. Aperture a small, round, terminal opening within a slightly raised 'shoulder'. Cement siliceous, presumably organic before fossilization.

Remarks: This species differs from Scherochorella minuta (Tappan) in its more coarsely agglutinated and thinner test wall. This species commonly occurs in great abundance in the studied well, typically making up $>50 \%$ of the agglutinated specimens present in a sample. It is most commonly present as broken fragments.
Suborder LITUOLINA Lankester 1885

Superfamily LITUOTUBACEA Loeblich and Tappan 1984

Family LITUOTUBIDAE Loeblich and Tappan 1984

Genus Paratrochamminoides Soliman 1972

Paratrochamminoides gorayskiformis Kender, Kaminski and Jones n. sp.

Plate 1, figures 7-10

Material: 12 specimens from 6 samples, Upper Oligocene to Lower Miocene.

PLATE 1

Scale bar $=200 \mu \mathrm{m}($ unless indicated $)$

1-6 Scherochorella congoensis n. sp. 1a-b. Holotype, Sample at 4,040m, 2-6. Paratypes, Sample at 4,040m.

7-10 Paratrochamminoides gorayskiformis n.sp.. 7a,b. Holotype, Sample at 3,850m, 8a,b. Paratype, samples at 3,830m, 9a,b. Paratype, sample at 3,830m, 10. Paratype, sample at $3,870 \mathrm{~m}$. 


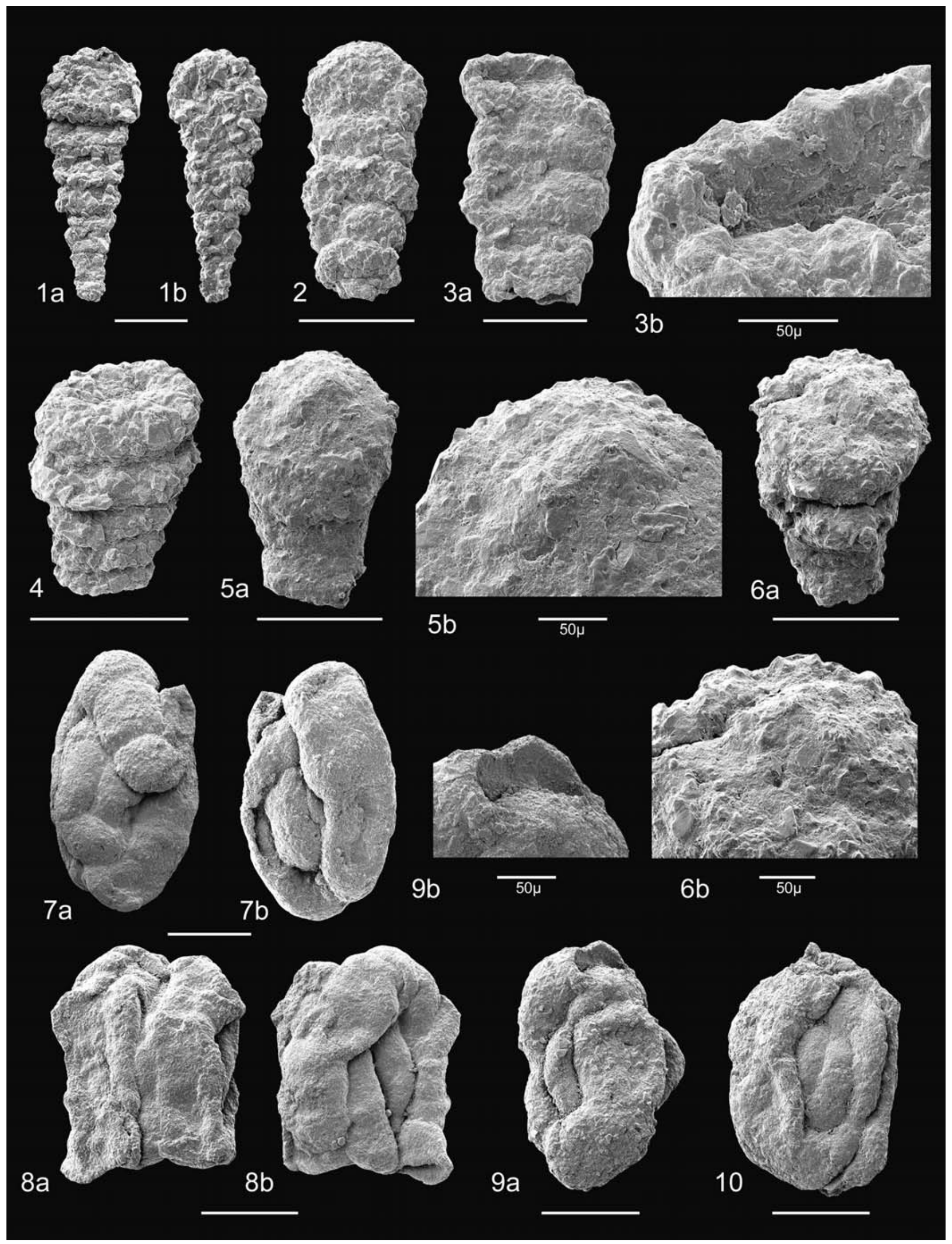


Type specimens: Holotype (BMNH PF 67320) and paratypes (BMNH PF 67321) are deposited in the micropalaeontological collections of the Natural History Museum, London.

Type localty: Congo Fan, offshore Angola, Block 31.

Type level: Cuttings sample collected at 3,850 meters below rotary table. Oligocene black shales.

Derivation of name: Taken from its similar appearance to Paratrochamminoides gorayskii (Grzybowski).

Description: Test oval in outline (approximately $0.6 \mathrm{~mm}$ in length). Coiling triloculine, coiled in three planes, with the long axis defined as in line with the intersection of the coiling planes. The tubular test is divided into chambers of varying length, from elongate to distinctly bead-like, approximately five in the last whorl. Wall is finely agglutinated with a fine to medium-coarse finish. Wall thin. Aperture at the open end of the tube. Cement siliceous, presumably organic before fossilization.

Remarks: This species is similar to Paratrochamminoides gorayskii (Grzybowski) in its coiling mode and shape, but can be distinguished by its shorter chamber length and thinner wall.

Superfamily LITUOLACEA de Blainville 1827

Family HAPLOPHRAGMOIDIDAE Maync 1952

Genus Haplophragmoides Cushman 1910

Haplophragmoides nauticus Kender, Kaminski and Jones n. sp. Plate 2, figures 1-2

Haplophragmoides sp.1 Kender, Kaminski and Cieszkowski 2005 , p. 267 , fig. 13 b.

Material: 45 specimens from 17 samples, Upper Oligocene to Lower Miocene.

Type specimens: Holotype (BMNH PF 67322) and paratypes (BMNH PF 67323) are deposited in the micropalaeontological collections of the Natural History Museum, London.

Type localty: Congo Fan, offshore Angola, Block 31.

Type level: Cuttings sample from 3,840 meters below rotary table. Oligocene black shales.

Derivation of name: After the Latin for 'nautical', after its association with the ocean.
Description: Test planispiral (up to $1 \mathrm{~mm}$ diameter), circular in outline, with an acute periphery. Coiling is evolute with 9 chambers in the final whorl. Chambers are truncated triangular (trapezoidal) in shape, increasing rapidly in size. Sutures are straight to sigmoidal, and slightly depressed. Wall simple, thin, finely agglutinated and finely finished. Aperture is slit-like, located at the base of the final chamber. Cement siliceous, presumably organic before fossilisation.

Remarks: This species differs from its most closely related form Haplophragmoides walteri (Grzybowski) by having a distinctly evolute coiling mode and the trapezoidal chambers. $H$. nauticus has been found from many localities within the Polish Carpathians, and was recently illustrated as Haplophragmoides sp. 1 (Kender et al., 2005) from the Lower Eocene of the Magura Unit, Outer Carpathians.

Suborder TROCHAMMININA Saidova 1981

Superfamily TROCHAMMINACEA Schwager 1877

Family TROCHAMMINIDAE Schwager 1877

Subfamily TROCHAMMININAE Schwager 1877

Genus Portatrochammina Echols 1971

Portatrochammina profunda Kender, Kaminski and Jones n. sp.

Plate 2, figures 3-8

Material: 206 species from 26 samples, Upper Oligocene.

Type specimens: Holotype (BMNH PF 67324) and paratypes (BMNH PF 67325) are deposited in the micropalaeontological collections of the Natural History Museum, London

Type localty: Congo Fan, offshore Angola, Block 31.

Type level: Cuttings sample 3,840 meters below rotary table. Oligocene black shales.

Derivation of name: After the Latin for 'deep', relating to its place of discovery in the distal part of the Congo Fan.

Description: Test free (up to $1 \mathrm{~mm}$ diameter). Coiling low trochospiral (both dextral and sinistral) with 3-4 whorls and 4-4.5 chambers in each whorl. Chambers are inflated and increase in size rapidly so that the final whorl makes up most of the test. Sutures depressed. Wall thin, with a rough surface made up of predominantly medium grains containing occasional coarse inclusions. Specimens are invariably flattened. Aperture a low umbilical-facing opening covered by an umbili-

\section{PLATE 2}

Scale bar $=200 \mu \mathrm{m}$ (unless indicated $)$

1-2 Haplophragmoides nauticus n. sp. 1a,b. Holotype, Sample at 3,840m, 2. Paratype, sample at 3,800m.

3-8 Portatrochammina profunda n. sp. 3a,b. Paratype, Sample at 3,860m, 4. Paratype, Sample at 3,830m, 5.
Paratype, Sample at 3,860m, 6a,b. Holotype, Sample at 3,840m, 7a,b. Paratype, Sample at 3,800m, 8 . Paratype, Sample at $3,860 \mathrm{~m}$. 


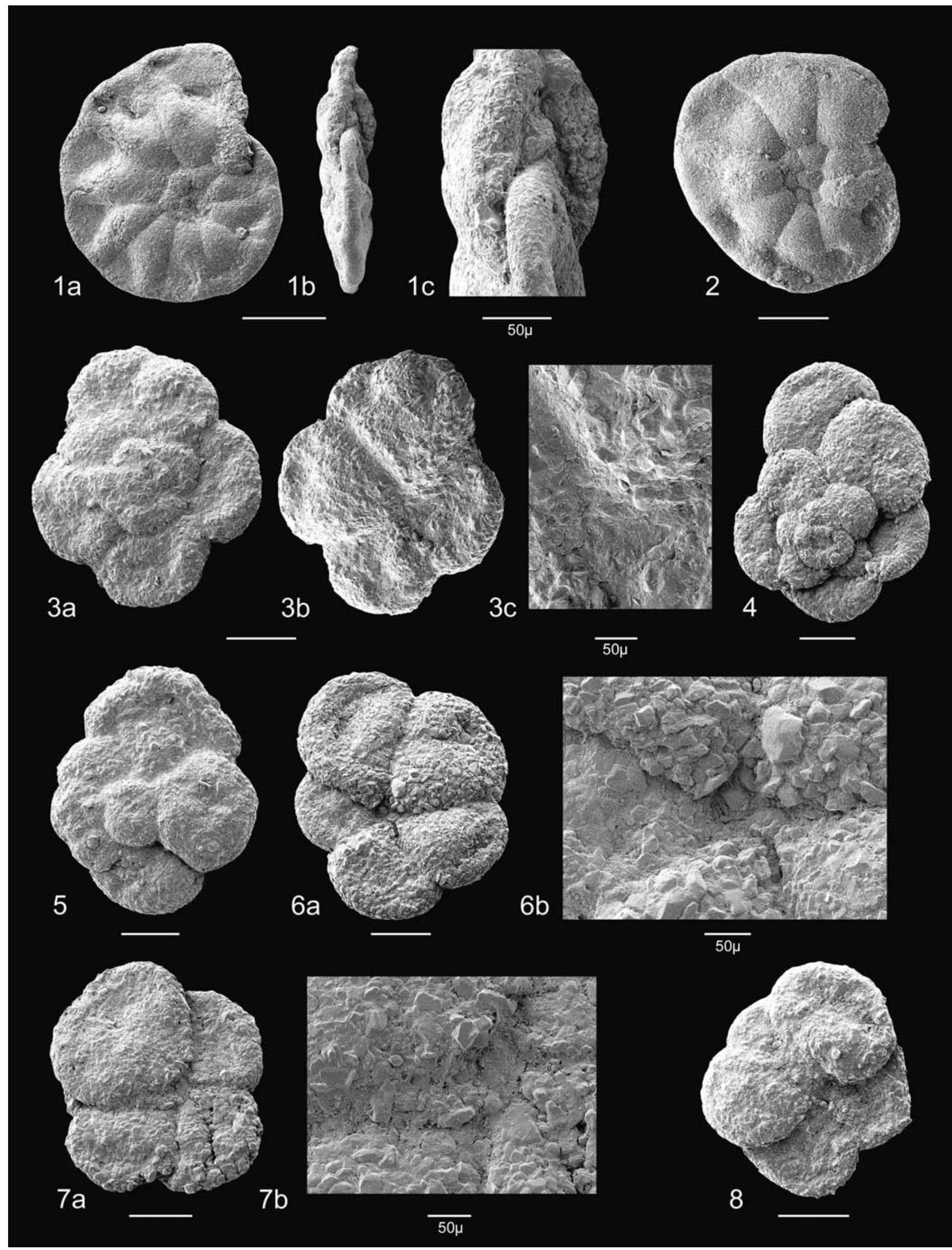


cal flap. Cement siliceous, presumably organic before fossilization.

Remarks: This species is similar to Trochammina trincherasensis Bermúdez, described from the Upper Oligocene of the Dominican Republic Trinchera Formation. Trochammina trincherasensis differs by having a typical trochamminid-like elongate apertural slit between the umbilicus and the periphery. It is described as having calcareous cement, although we believe it more probable that this is not the case. Portatrochammina profunda n.sp. can occur in high abundance in the studied well.

\section{ACKNOWLEGMENTS}

The senior author is grateful for financial support from British Petroleum. We thank John Gregory, Janice Weston and Clive Jones for pre-reviewing the initial draft of the manuscript.

\section{REFERENCES}

ANKA, Z. and SÉRANNE, M., 2004. Reconnaissance study of the ancient Zaire (Congo) deep-sea fan (ZaiAngo Project). Marine Geology, 209: 223-244.

BABONNEAU, N., SAVOYE, B., CREMER, M. and KLEIN, B., 2002. Morphology and architecture of the present canyon and channel system of the Zaire deep-sea fan. Marine and Petroleum Geology, 19: 445-467.

KAMINSKI, M.A., 2004. The Year 2000 classification of agglutinated foraminifera. In: Bubik, M., and Kaminski, M.A., Ed. Proceedings of the Sixth International Workshop on Agglutinated Foraminifera, 237-255. London: Grzybowski Foundation Special Publication 8.

KENDER, S., KAMINSKI, M. A. and CIESZKOWSKI, M., 2005. Foraminifera from the Eocene Variegated Shales near Barwinek (Magura Unit, Outer Carpathians), the type locality of Noth (1912) revisited. Annales Societatis Geologorum Poloniae, 75(3): 249-272.

LAVIER, L. L., STECKLER, M. S. and BRIGAUD, F., 2001. Climatic and tectonic control on the Cenozoic evolution of the West African margin. Marine Geology, 178: 63-80.

LOEBLICH, A. R. and TAPPAN, H., 1984. Some new proteinaceous and agglutinated genera of Foraminiferida. Journal of Paleontology, 58: $1158-1163$

PREECE, R.C., KAMINSKI, M.A. and DIGNES, T.W. 1999. Miocene benthonic foraminiferal morphogroups in an oxygen minimum zone offshore Cabinda. In: Oil and Gas Habitats of the South Atlantic, 267-282. Geological Society Special Publication, 153.

2000. Popovia johnrolandi n. sp., a new smaller agglutinated foraminifera from northern Venezuela: a biostratigraphical example of the second law of thermodynamics. In: Hart, M.B., Kaminski, M.A., and Smart, C.W., Ed., Proceedings of the Fifth International Workshop on Agglutinated Foraminifera, 403-410. Grzybowski Foundation Special Publication, 7.

Manuscript received June 15, 2006

Manuscript accepted September 10, 2006 